debilitating degree (p. 255). As for Libya, it experienced what Sultany calls "vacuous inclusion," its constitutional process taking shape in a context of severe state weakness (p. 260).

All of these cases of constitution-making in the context of revolution illustrate that the rule of law is not free of the vicissitudes of politics or the weight of history. They also reveal the inadequacy of various approaches to constituent power. These include theories advanced by "populist" philosophers reflecting all colors of the political rainbow (from the Abbe Sieyès to Carl Schmitt and from Ernst-Wolfgang Böckenförde to Antonio Negri), as well as "constitutionalist" theorists ranging from Hannah Arendt to Hans Lindahl. By virtue of his command of the literature, Sultany is able to map the theoretical terrain with precision, showing how populists differ from constitutionalist in so far as the former insist on a limitless constituent power that is inexhaustible and the latter call for "lawful" limits to democratic will and see constitutional enactment as a terminal point (p. 290). The judiciary in Egypt and Tunisia effectively rejected the populist approach, constraining popular will to a great degree, contributing with their rulings to the extinguishment of its flames (p. 321). Their practices, however, did not achieve a synthesis between constituent power and constitutional form of the sort desired by constitutionalists nor did they prevent the instability and violence that the latter dreaded the most. Sultany correctly infers from this that "constitutional legitimations are no more than validations based on abstract principles whose applications and interpretations are controversial and contested" (p. 321).

While Sultany demonstrates the incoherence of revolutionary constitutional processes, he distinguishes between them and the reformist constitutionalism that took place in the context of the Arab Spring in Morocco, Jordan, Bahrain, Oman, and Algeria. As much as revolutionary models were deficient in their application of popular sovereignty as well as participation, reformist exercises comprehensively excluded both. In all of the countries surveyed, the reigning executive power installed reform committees lacking in any serious input from the citizenry, arriving at documents that were normatively vacuous, failing to increase regime accountability or to expand the rights of citizens (p. 287). Notwithstanding the major differences between revolutionary and reformist models, Sultany once again resists the temptation of overlooking their commonalities. When it comes to outcomes, these models, he suggests, differ in degree rather than in kind, the reformist version being simply more radically exclusionary. As for similarities, they can be seen in the shared heightened concern with the stability of the existing or the emerging regime, in the common failure to constrain executive power, and in the persistence of strong continuities with the past (p. 288).

The sober picture painted by Sultany should not mask his evident commitment to emancipatory potentialities. This is clearly manifested in the afterward, in which he laments the "faltering of revolution" that occurred after the initial moments of hope. Far from providing a cautionary tale against revolution, his book calls for a more revolutionary approach to law. As was proven by the events that took place in Algeria and Sudan after the publication of Law and Revolution, he was right to conclude that "perhaps the Arab Spring has not ended yet" (p. 324).

\title{
Local Politics in Jordan and Morocco: Strategies of Centralization and Decentralization. Janine A. Clark (New York: Columbia University Press, 2018). Pp. 416. $\$ 65.00$ cloth. ISBN: 9780231183581
}

Sylvia I. Bergh, International Institute of Social Studies, Erasmus University Rotterdam, The Hague, The Netherlands; e-mail: bergh@iss.nl

In Local Politics in Jordan and Morocco, Janine Clark compares the decentralization reforms in Morocco and Jordan to answer the main question of why some authoritarian regimes engage in decentralizing

(C) The Author(s), 2020. Published by Cambridge University Press. This is an Open Access article, distributed under the terms of the Creative Commons Attribution licence (http://creativecommons.org/licenses/by/4.0/), which permits unrestricted re-use, distribution, and reproduction in any medium, provided the original work is properly cited. 
government and administrative institutions (as in Morocco) while others do not (as in Jordan). Her main argument is that these reforms, as (perhaps naively) pushed by global institutions as part of the neoliberal "good governance" agenda, are in fact a way for authoritarian rulers to remain in power. Clark draws on detailed historical accounts as well as in-depth qualitative field research to build this argument, aided by a logical chapter sequence.

In Morocco, devolving some responsibilities to the municipal level since the 1960s has allowed the monarchy to pursue coalition strategies and co-opt the main opposition parties (most recently, the Parti de la Justice et du Développement, PJD, Justice and Development Party), while pro-regime parties were able to develop patron-client ties. By pursuing an ambiguous or even cynical decentralization strategy, i.e., one that devolved some powers and responsibilities to local governments while simultaneously undermining their autonomy and developmental capacities (including through the clever use of legal ambiguities about the municipalities' roles), the monarchy was able to "blame them for all servicedelivery failures and then using their failures as justification to 'come to the rescue' of the citizens by bypassing elected officials and bringing services directly to the people" (p. 277). The latter was done through "technocratic" programs such as the National Initiative for Human Development (known by its French acronym, INDH), in which appointed officials in the Ministry of the Interior play a decisive role in allocating funds to local civil society actors. In fact, given the widespread phenomenon of local political leaders establishing their own associations, Clark argues that "civil society has become an important arena, if not the most important arena, of political competition with [all] political parties [...] pursuing their goals via civil society" (p. 282).

The book also includes a chapter on the PJD's ascent to national power in the 2015 elections, and Clark uses it to argue that "it was only through its civil society activism that the PJD was able to prove its technocratic skills and its commitment to the values of good governance and through its partnerships with civil society activists that it came to power" (p. 282). Clark provides a nuanced argument about the PJD's effects. On the one hand, through its sound management of municipal affairs, the PJD "undermines the foundations on which the representatives of the central authorities justify state interference in municipal affairs," but on the other hand, "the PJD [...] serves to politically elevate a depoliticized civil society" which presents no threat to the dominant power structures (p. 284). Chapter 6 makes it clear that on balance, the PJD does not destabilize the regime.

As for Jordan, Clark argues convincingly that centralization has fragmented pillars of regime support. The processes are similar to the ones taking place in Morocco, i.e., the central government repeatedly imposed seemingly superior technocrats, such as municipal managers or executive directors, who undermine mayors' positions. However, the main difference with Morocco lies in the fact that centralization has served to undermine political parties and reinforce tribalism (mainly through an electoral system which favors tribal independents at the expense of political parties), "while simultaneously making the latter less effective as a source of regime stability"(p. 284). While the Jordanian monarchy has historically privileged the Transjordanian population as its main coalition partner, shrinking resources and a crisis in municipal service provision have led to increased competition between tribes and fragmentation along clan and family lines, and ultimately, its growing alienation from the regime. In the current context of dramatic shifts in the ethnic makeup of the Jordanian population, the monarchy still relies on the support of the countryside, despite also fostering a new urban elite made up of businessmen and bourgeoisie. Clark uses her extensive fieldwork data to illustrate the municipalities' dependence on the center (both for financial support and wasta, i.e., connections that allow calling on favors from MPs, ministers, or the king) and local leaders' frustrations at their inability to develop the municipalities considerable economic (and tourism) potential.

Overall, the book shows that by aiding the spread of elite capture, decentralization strategies have been used to undermine democratic practice rather than aiding any democratic transition. The study's main finding is thus counterintuitive: it shows "how decentralization provides a greater stabilizing function for authoritarian regimes than does centralization" (p. 7). Clark concludes insightfully by arguing that "rather than being the driver of democratization, good governance and decentralization appear to be contingent on democratization" (p. 288), and calls on international donors to pay more attention to elite capture and clientelist ties that pervade the political system. It seems easy to agree with Clark that the 
solution lies in establishing a strong party system modelled after Western-style democracies. However, it is far from obvious how this could be achieved.

While generally very well written and easy to follow, the book has a few shortcomings. Key concepts such as "state," "regime," and "monarchy" are not sufficiently clarified. For example, Clark writes in the conclusion that "while the two states have withdrawn, their disaggregation has allowed a more direct route by which each monarch may engage in coalition strategies" (p. 283). What is meant here by "states"? The state bureaucracy? But if so, does this not contradict the earlier argument about appointed officials undermining elected (political) representatives at the local level? Similarly, the terms "tribes" and "clans" could be more precisely defined. Second, although the bulk of fieldwork for this book was conducted from 2010 to 2012, it is regrettable that the 2015 decentralization reforms in Morocco were not at least referred to; the Municipal Charter (Organic Law) of 2015 brought about quite some significant changes in the local planning process and it would have been useful to update some of the findings, especially with regard to the Municipal Development Plans. Similarly, the discussion on civil society in Morocco could have included some references to the growing grassroots protest movements made up of "unorganized" civil society, namely ordinary and mostly young citizens who do not represent the pro-regime civil society elite which has gained so much from decentralization reforms.

Despite these minor shortcomings, I strongly recommend this book to all students and scholars of local politics in the MENA region for its fascinating account of how power is reconfigured at the local level and what this means for regime stability. By giving voice to local leaders who are notoriously difficult to study, Clark has made a valuable contribution to the scholarly literature on decentralization, which still tends to be dominated by (a-political) macro-level analyses on the effects of decentralization reforms on public investment levels, economic growth, macroeconomic stability, or education and health outcomes, rather than grounded analyses of their actual practice.

\section{Gendered Morality: Classical Islamic Ethics of the Self, Family and Society. Zahra Ayubi, (New York: Columbia University Press, 2019). Pp. 368. $\$ 35.00$ paper. ISBN: 9780231191333}

Merin Shobhana Xavier, School of Religion, Queen's University, Kingston, Canada; e-mail: shobhana. xavier@queensu.ca

Zahra Ayubi's Gendered Morality is a brilliant analysis of the ways in which gender hierarchies are constructed in classical Islamic philosophy. The book is based on three key Persian philosophical treatises on ethics (akhlāq texts) that range from the 12th to the 15th centuries. They include Kimiya-i Sa'adat or The Alchemy of Happiness by Abu Hamid Muhammad al-Ghazali (d. 1111); Akhlaq-i Nasiri or The Nasirean Ethics by Nasir ad-Din Tusi (d. 1274); and Akhlaq-i Jalali or The Jalalean Ethics by Jalal ad-Din Davani (d. 1502). Despite the texts' differing theological orientations and the authors' varied social locations, all three of these treatises were written for an elite male audience. As such, Ayubi posits that these texts serve as exemplary illustrations of the ways in which Muslim male scholars constructed ideas of the self (nafs) based on principles of cosmic justice and wholeness, while simultaneously reaffirming a tenuous, restrictive and gendered humanity. The study masterfully weaves metaphysical, cosmological, and philosophical queries together, as well as social and anthropological realities of justice, social norms, and values.

The book is divided into four main chapters with an introduction and a conclusion. The first chapter historically situates akhlāq literature, as well as Ayubi's analytical approaches and methodological justifications. The main crux of the arguments are divided between Chapters 2 to 4 , which are thematically organized across three central relations that are key for ethical refinement: that is the individual (metaphysical self), the self in marriage, and the self in social contexts. 